\title{
EFFECT OF SOME ORGANIC MANURES AND POTASSIUM ADDITION ON GROWTH, YIELD AND FRUIT QUALITY OF SULTANI FIG TREES \\ Gowda, A. M.
}

Olive and Semi - Arid Zone Fruits Res., Hort. Res. Instit., Agric. Res. Center, Giza, Egypt

\begin{abstract}
An experiment was carried out in a private orchard situated at Nasser District, Beni-Sweif Governorate to investigate the effect of some organic manure sources (cattle, sheep and chicken manures) as soil and / or foliar application of potassium and their combinations on growth, yield and fruit quality of Sultani fig trees grown on clay loamy soil during two successive seasons of 2005 and 2006. Data revealed that, the highest records of trunk and canopy circumferences were obtained from the fertilized trees with sheep manure and cattle manure, while chicken manure application gave the tallest shoots. Moreover, the highest values of leaf area, fresh weight and number of leaves/ shoot were recorded from trees treated with sheep and chicken manures. Meantime, cattle manure gave the heaviest leaf dry weight. Trees received $750 \mathrm{gm} \mathrm{K} \mathrm{K}_{2} \mathrm{O}$ in potassium sulphate form $\left(48 \% \mathrm{~K}_{2} \mathrm{O}\right)$ plus foliar potassium $(1 \%)$ gave the highest values in most of the studied growth parameters in both seasons.

The data also cleared that, Sultani fig trees fertilized with sheep and cattle manure gave the highest number of breba fruits/ tree, number of main fruits/ shoot and /tree, yield ( $\mathrm{kg} /$ tree), main fruit weight, diameter and height of fruit, TSS and total sugars. On the contrary, the same treatment gave the lowest values of total acidity and fruit moisture content. However, the application of 750 or $500 \mathrm{gm} \mathrm{K}_{2} \mathrm{O}$ and foliar potassium $1 \%$ don't give significant differences on yield of Sultani fig trees. Whereas, the addition of $750 \mathrm{gm} \mathrm{K} \mathrm{K}_{2} \mathrm{O}$ + foliar $1 \%$ potassium surpassed of the treatments for fruit quality characters (except for total acidity and fruit moisture content). Moreover, the results showed that sheep manure when supplemented with $750 \mathrm{gm} \mathrm{K}_{2} \mathrm{O}$ and foliar $1 \%$ potassium gave the highest values for most of the studied characters in both seasons. As for Leaf nitrogen, phosphorus and potassium contents, sheep manure treatments increased leaf nitrogen and phosphorus contents, however chicken manure gave the highest content of potassium. The application of $500 \mathrm{gm} \mathrm{K} \mathrm{K}_{2} \mathrm{O}+$ foliar $1 \%$ potassium gave the highest leaf nitrogen and phosphorus contents in both seasons.

It can be recommended that, sheep or cattle manure and potassium addition at $500 \mathrm{gm} \mathrm{K} \mathrm{K}_{2} \mathrm{O}$ tree as soil application + foliar $1 \%$ potassium can give the highest yield with the best fruit quality under the same conditions of this study .
\end{abstract}

\section{INTRODUCTION}

Figs (Ficus carica Risso) are considered one of the most popular deciduous fruit trees in Egypt. Sultani fig cultivar is the most widely grown and considers the local standard cultivar. The total fig acreage in Egypt is estimated by 77.227 feddans and fig production attained 160.124 tons of fresh fruits (according to the statistics of the Ministry of Agricultural, 2004). A great attention has been focused on using organic fertilizers in fruit production in order to reduce plant and soil pollutions and its effect on human health. Organic manures improve the physical, chemical and biological 
Gowda, A. M.

properties of nearly all soil types, adjusting soil $\mathrm{Ph}$, increasing solubility and nutrients availability to plant consequently, influence the growth and production of the plants ( Madison et al., 1986; Mengel and Kirkby, 1987 and Zhou et al., 2001). The using of animals manures will be monitored more closely, especially in terms of nutrient leaching on highly permeable soils (Ferguson,1994). The addition of organic manures to the soil encouraged proliferation of soil microorganisms, increased microbial population and activity of microbial enzymes i.e. dehydrogenase, urease and nitrogenase (Youssef et al., 2001 and Abou-Hussein et al., 2002). Some investigators studied the effect of organic manure application as compared with mineral fertilizers on different fruit crops (El-Adawy,1987; Mordogan, et al., 2002; Caetano, et al ., 2006) on fig , ( Abou- Taleb , 2004) on pecan, (Kassem \& Marzouk, 2002) on grapevines (Foud et al., 2002; Gamal \& Ragab, 2003 ; Abd El-Naby, 2004 and Abd El- Naby et al., 2004) on citrus and (Haggag, 1996) on olive trees. They reported that, under organic system soil biotic life increased as a result of the plant synthesis of more vitamins and amount of total sugars. Moreover, the addition of organic fertilizer is necessary for the best growth, greater yield and fruit quality when compared to mineral fertilizers. Potassium is one of the most important essential elements, when supplied to the soil . It plays a dominant role in the mineral nutrition of fruit crops. The need for potassium may be widespread because the fruits consume more potassium than any other nutrient element (Chapman, 1968 and Koo, 1985). Potassium availability in soils could also be influenced by moisture content, plant withdrawal rates, temperature and other factors ( Koo, 1985). The objective of this study is to demonstrate the effect of different organic manure sources and potassium addition on tree growth, yield and fruit quality of Sultani fig trees.

\section{MATERIALS AND METHODS}

This study was conducted during 2005 and 2006 growing seasons on twenty years old Sultani fig trees grown in a private orchard situated at Nasser District, Beni-Sweif Governorate $(15 \mathrm{kms}$ North-East, Beni-Sweif city).The trees were planted in a square system of four meters apart and received the same horticultural management. They were vase trained to equal number of bearing units (20 per tree with 8 buds each) and grown on clay loamy soil under flood irrigation system. Physical and chemical properties of the surface soil $(0.0-90 \mathrm{~cm})$ were determined according to Wild et al., (1985) and data are shown in Table (1).

A factorial experiment was carried out to investigate the response of Sultani fig trees to some organic manure sources and potassium fertilization addition during 2005 and 2006 seasons.

\section{Organic manure treatments:}

Cattle manure, sheep manure, chicken manure and control (without organic manure). The chemical analysis of the three used manures are shown in Table (2). 
The three organic fertilizers were applied superficially and mixed into the root zone under the shedding of the tree canopy in mid-December of each season at the recommended basal dressing fertilizer for fig tree $300 \mathrm{gm}$ $\mathrm{N}$ from mineral source as ammonium sulphate form $(20.5 \% \mathrm{~N})$ and another $300 \mathrm{gm} \mathrm{N}$ from organic source, consequently, each tree received $600 \mathrm{gm} \mathrm{N}$. The rates of application of organic manure sources and potassium fertilization addition are shown in Table (3).

Potassium fertilization treatments; Potassium treatments were applied as follows:

k1 : $500 \mathrm{gm} \mathrm{K}_{2} \mathrm{O}$ / tree as soil application (1.042 $\mathrm{kg}$ potassium sulphate). k2 : $750 \mathrm{gm} \mathrm{K} \mathrm{K}_{2} \mathrm{O} /$ tree as soil application ( $1.563 \mathrm{~kg}$ potassium sulphate).

k3 : $k 1$ + foliar spray with $1 \%$ potassium.

K4 : k2 + foliar spray with $1 \%$ potassium.

K5 : only foliar spray with $1 \%$ potassium .

Table (1): Mechanical and chemical analysis of the experimental soil.

\begin{tabular}{|l|l|}
\hline Parameters & Mechanical analysis \\
\hline \multicolumn{2}{|c|}{} \\
\hline Sand \% & Value \\
\hline Silt \% & 22.22 \\
\hline Clay \% & 29.32 \\
\hline Texture & 48.46 \\
\hline \multicolumn{2}{|c|}{ Chemical analysis } \\
\hline Organic matter & Clay loam \\
\hline PH (1:2.5 suspension) & 1.58 \\
\hline E.C mmhos/cm 1:2.5 & 7.78 \\
\hline \multicolumn{2}{|c|}{ Available nutrients } \\
\hline N \% & 1.04 \\
\hline P ppm & 0.08 \\
\hline K ppm & 15.20 \\
\hline Fe ppm & 202.5 \\
\hline Mn ppm & 33.0 \\
\hline Zn ppm & 19.0 \\
\hline
\end{tabular}

Table (2): Analysis of the three selected manures.

\begin{tabular}{|l|c|c|c|c|c|c|}
\hline \multirow{2}{*}{ Character } & \multicolumn{2}{|c|}{ Cattle manure } & \multicolumn{2}{c|}{ Sheep manure } & \multicolumn{2}{c|}{ Chicken manure } \\
\cline { 2 - 7 } & $\begin{array}{c}\mathbf{1}^{\text {st }} \\
\text { season }\end{array}$ & $\begin{array}{c}\mathbf{2}^{\text {nd }} \\
\text { season }\end{array}$ & $\begin{array}{c}\mathbf{1}^{\text {st }} \\
\text { season }\end{array}$ & $\begin{array}{c}\mathbf{2}^{\text {nd }} \\
\text { season }\end{array}$ & $\begin{array}{c}\mathbf{1}^{\text {st }} \\
\text { season }\end{array}$ & $\begin{array}{c}\mathbf{2}^{\text {nd }} \\
\text { season }\end{array}$ \\
\hline Weight of $\mathbf{~ m}^{\mathbf{3}} / \mathbf{k g}$ & 340 & 340 & 464 & 420 & 260 & 510 \\
Humidity\% & 8.0 & 10.3 & 9.6 & 8.6 & 8.7 & 13.9 \\
Organic matter\% & 39.47 & 71.51 & 72.32 & 74.95 & 36.76 & 52.3 \\
Organic carbon\% & 22.89 & 41.48 & 41.55 & 43.47 & 21.32 & 24.51 \\
N\% & 1.38 & 1.85 & 2.35 & 2.72 & 4.17 & 4.1 \\
P\% & 0.68 & 0.94 & 1.02 & 1.09 & 0.73 & 1.02 \\
$\mathbf{K} \%$ & 1.86 & 2.37 & 2.11 & 2.29 & 1.90 & 1.58 \\
$\mathbf{C : N ~ r a t i o ~}$ & 19.4 & 22.4 & 18.8 & 16.5 & 5.1 & 8.4 \\
Fe ppm & 4174 & 4410 & 6645 & 6100 & 4296.6 & 4483.1 \\
Mn ppm & 327.8 & 299 & 242.3 & 259 & 212.5 & 257 \\
$\mathbf{Z n ~ p p m ~}$ & 79.3 & 43 & 109 & 61 & 792.9 & 250 \\
\hline
\end{tabular}


Gowda, A. M.

Table (3): Organic fertilizers and potassium application rates

\begin{tabular}{|c|c|c|c|c|c|c|}
\hline \multirow[b]{2}{*}{ Rates / Treatment } & \multicolumn{2}{|c|}{ Cattle manure } & \multicolumn{2}{|c|}{ Sheep manure } & \multicolumn{2}{|c|}{ Chicken manure } \\
\hline & $\begin{array}{c}1^{\text {st }} \\
\text { season }\end{array}$ & $\begin{array}{c}2^{\text {nd }} \\
\text { season }\end{array}$ & $\begin{array}{c}1^{\text {st }} \\
\text { season }\end{array}$ & $\begin{array}{c}2^{\text {nd }} \\
\text { season }\end{array}$ & $\begin{array}{c}1^{\text {st }} \\
\text { season }\end{array}$ & $\begin{array}{c}2^{\text {nd }} \\
\text { season }\end{array}$ \\
\hline $\begin{array}{l}\text { Organic manure rates as } \\
\text { the basal of } 300 \mathrm{gm} \mathrm{N} / \\
\text { tree }\end{array}$ & 21.8 & 16.2 & 12.8 & 11.0 & 7.2 & 7.4 \\
\hline $\begin{array}{l}\text { Potassium in the rate of } \\
\text { organic source }\left(\mathrm{gm} \mathrm{K}_{2} \mathrm{O}\right. \\
\text { (tree) }\end{array}$ & 405.5 & 383.9 & 270.1 & 251.9 & 136.8 & 116.9 \\
\hline \multicolumn{7}{|c|}{ Supplementary of potassium treatments from potassium sulphate $\left(48 \% \mathrm{~K}_{2} \mathrm{O}\right)$} \\
\hline $500 \mathrm{gm} \mathrm{K}_{2} \mathrm{O} /$ tree & 94.5 & 116.1 & 229.9 & 248.1 & 363.2 & 383.1 \\
\hline $750 \mathrm{gm} \mathrm{K}_{2} \mathrm{O} /$ tree & 344.5 & 366.1 & 479.9 & 498.1 & 613.2 & 633.1 \\
\hline
\end{tabular}

Potassium soil application was in two equal doses during May and August of each year, while potassium addition as foliar application was added at three times May, June and July from a compound contains $36 \%$ potassium. The applied rates of potassium were calculated on the basal of potassium content in organic manure application rate as shown in Table (3).

\section{Experimental layout:}

Sixty homogenous Sultani fig trees were chosen and arranged in a factorial experiment split plot design of twenty treatments, three replicates /each and represented with one tree. The main is organic manure sources (control, cattle manure, sheep manure and chicken manure) and the sub plot is potassium treatments $\left(500,750 \mathrm{gm} \mathrm{K} \mathrm{K}_{2} \mathrm{O} /\right.$ tree and /or foliar potassium 1 $\%)$.

This study was evaluated through the following measurements:

I- Growth parameters.

1-Tree characteristics: Trunk circumference for each tree was measured at the beginning and the end of the experiment in the two seasons of study, the net increase of trunk circumference $(\mathrm{cm})$ was calculated. Canopy circumference $(\mathrm{m})$ was measured. Shoot length $(\mathrm{cm})$ was recorded at November of each season on ten shoots per tree which tagged at random for all tree directions at the beginning of each growing season.

2- Leaf characteristics: Leaf area $\left(\mathrm{cm}^{2}\right)$ was measured by planimeter on 20 mature leaves from each tree in August, cleaned to remove the dust and washed to record fresh weight of leaf $(\mathrm{gm})$. Leaf samples were dried at $70^{\circ} \mathrm{C}$ until constant weight to determine the dry weight of leaf (gm).

Number of leaves / shoot was recorded at the end of October of each season.

II -Yield and fruit quality.

1- Yield: Number of breba fruits / tree , number of main fruits per shoot and per tree and main yield $(\mathrm{kg}) /$ tree ( number of main fruits / tree $\times$ average main fruit weight ).

2-Fruit quality: At the second half of August, 15 fruits per each selected tree were randomly harvested for measuring the following determiniation :

- Average main fruit weight.

- Fruit height and diameter $(\mathrm{cm})$ were estimated using a Varnier Caliper. 
- Fruit moisture percentage was determined by drying at $70^{\circ} \mathrm{C}$ till constant weight.

- Total soluble solids percentage (T.S.S. \%) was estimated using hand refractometer.

- Total acidity was determined as citric acid by titrating diluted flesh against $0.1 \mathrm{~N} \mathrm{NaOH}$ using phenolphthalein as an indicator.

- Total sugars was estimated according to the method of Lane and Eynon as outlined in A.O.A.C. (1975).

III- Leaf mineral composition. Dry leaf samples were grounded and digested according to (Chapman and Pratt, 1978) for the following determinations :

-Total nitrogen: was determined by micro-Kjeldahl method (Jackson, 1973). -Phosphorus: was determined according to the method of Murphy and Riley (1962).

-Potassium: was determined by Flame Photometer (Jackson, 1973).

Statistical analysis :

All data obtained during the three experimental seasons were subjected to analysis of variances according to Snedecor and Cochran, (1980) and means were differentiated using Multiple Range Test (Duncan, $1955)$ at the $5(\%)$ level of probability.

\section{RESULTS AND DISCUSSION}

\section{I-Growth parameters .}

1-Tree characteristics:

Results in Table (4) clearly show that, cattle, sheep and chicken manure sources significantly improved trunk \& canopy circumference and shoot length compared to the control. In this respect, sheep manure and cattle manure had the best values of net increase in trunk circumference and canopy circumference, while chicken manure gave the tallest shoot length in 2005 and 2006 seasons .

Meanwhile, the specific effect of potassium treatments was significant for all characteristics. It can be noticed that, there was a gradual increase in trunk \& canopy circumference and shoot length values. For the same characters, the trees which treated with $750 \mathrm{gm} \mathrm{K} 2 \mathrm{O}$ plus foliar potassium $1 \%$ had the highest values.

Regarding the interaction between organic manure sources and potassium additions increased significantly shoot length in 2006 season. In this concern, the combination representing chicken manure $+750 \mathrm{gm} \mathrm{K} \mathrm{K}_{2} \mathrm{O}$ plus foliar potassium $1 \%$ was the most effective treatment. These results are in agreement with El-Adawy,(1987) and Mordogan, et al.,(2002) on fig ; AbouTaleb, (2004) on pecan and Abd El-Naby et al., (2004) on citrus.

2- Leaf characteristics:

It is quite evident as shown from data in Tables $(5 \& 6)$ that, the four investigated leaf parameters (leaf area, leaf fresh \& dry weight and number of leaves / shoot) were significantly different in response to organic and potassium treatments. 
Gowda, A. M.

4

1278 
J. Agric. Sci. Mansoura Univ., 32 (2), February, 2007

5 
Gowda, A. M.

Generally, organic manure sources additions significantly succeeded to improve the aforesaid leaf characters compared with the control treatment. Herein, chicken and sheep manures had the highest values of leaf area, leaf fresh weight and number of leaves /shoot during both seasons of study. Moreover, sheep manure fertilizer (in $1^{\text {st }}$ season) and cattle and sheep manures (in $2^{\text {nd }}$ season) gave the highest records of leaf dry weight.

Potassium treatments show significant values of leaf parameters. Whereas the trees received both soil and foliar potassium had the highest values compared with the applied trees with soil or foliar application in 2005 and 2006 seasons. In this respect, soil potassium addition at $750 \mathrm{gm} \mathrm{K} 2 \mathrm{O}+$ foliar potassium at $1 \%$ was superior in both seasons.

The interaction effect on leaf dry weight was significant in both seasons. However, its effect on leaf area, leaf fresh weight and number of leaves / shoot was not significant especially in the first season. The highest values of leaf area and leaf fresh weight were obtained when the trees treated with chicken, sheep and cattle manures with $750 \mathrm{gm} \mathrm{K} \mathrm{K}_{2} \mathrm{O}$ + foliar $1 \%$ potassium . Sheep manure $+750 \mathrm{gm} \mathrm{K}_{2} \mathrm{O}+$ foliar potassium $1 \%$ gave the heaviest leaf dry weight and the highest number of leaves / shoot.

The enhancement of different growth parameters due to organic fertilizers may be attributed to the positive effect of organic materials on increasing the availability of most nutrients and improving physical and chemical properties of soil which in turn increase nutritional status and growth of the tree (Nijjar, 1985). Moreover, organic manures increase the microorganisms activity in soils which produce growth promoting substances consequently increase the plant growth. This increase in plant growth may increase the photosynthetic rates leading to an increase of the assimilation rates. The present results of using organic fertilizers was supported by the results of El-Adawy, (1987) and Mordogan, et al., (2002) on fig ; Abou - Taleb ,2004) on pecan and Abd ElNaby et al., (2004) on citrus. Moreover, the improvement of growth parameters reflects enhancing potassium for uptake of more nutrients via roots and accumulation in the leaves, that activated the growth processes of the shoots. Similar response was reported by Abdel-kader and Sabbah, (2002) on pomegranate .

\section{II -Yield and fruit quality.}

1- Yield:

Number of breba fruits / tree: number of breba fruits /tree as affected by different organic manure sources and potassium additions is presented in Table (6).The data indicated that, both organic treatments and potassium addition significantly increased the number of breba fruits /tree as compared to the control during the two seasons of study. Sheep and cattle manures were more effective than chicken manure .

Increasing the potassium addition from 500 to $750 \mathrm{gm} \mathrm{K}_{2} \mathrm{O} /$ tree with or without foliar potassium 1\% increased number of breba fruits /tree in 2005 and 2006 seasons. The interaction was significant specially in the second season and the highest values were recorded from those trees treated with cattle manure and supplemented with $750 \mathrm{gm} \mathrm{K}_{2} \mathrm{O}+$ foliar potassium $1 \%(\mathrm{~K} 4)$. 
Number of main fruits per shoot: It was also noticed from data in Table (6) that, the differences as a result of treatments were significant. Trees fertilized with sheep manure had the best significant values as compared to all other treatments in the first and second seasons.

In addition,soil potassium application with foliar spraying exhibited the highest records of number of main fruits /shoot in both studied seasons. The differences between 500 or $750 \mathrm{gm} \mathrm{K} \mathrm{K}_{2} \mathrm{O} /$ tree + foliar potassium $1 \%$ treatments were not significant in 2005 and 2006 seasons. The interaction was insignificant in both seasons.

Number of main fruits / tree: Data presented in Table (7) indicated that, Sultani fig trees produced higher number of main fruits when fertilized with sheep and cattle manure followed by chicken manure treatmentthan control in both seasons .

Regarding the effect of potassium addition, the trees fertilized with $750 \mathrm{gm}$ $\mathrm{K}_{2} \mathrm{O} /$ tree + foliar potassium $1 \%(\mathrm{~K} 4)$ had the greatest number of main fruits /tree. Moreover, the differences between the treatments ( K4) and $500 \mathrm{gm}$ $\mathrm{K}_{2} \mathrm{O}$ + foliar potassium $1 \%(\mathrm{~K} 3)$ were not significant during both studied seasons. The interaction was not significant in 2005 and 2006 seasons.

Main yield (kg) / tree: Data in Table (7) shows that applying organic manures significantly increased the yield /tree compared with the control. The trees fertilized with sheep manure gave higher yield followed by cattle manure and chicken manures in both seasons.

The effect of potassium addition was significant in 2005 and 2006 seasons. Whereas, values of the treatment included addition of $750 \mathrm{gm} \mathrm{K} \mathrm{K}_{2} \mathrm{O} /$ tree + foliar potassium $1 \%(\mathrm{~K} 4)$ don't give significant values related to that treated with $500 \mathrm{gm} \mathrm{K} \mathrm{K}_{2} \mathrm{O} /$ tree + foliar potassium $1 \%(\mathrm{~K} 3)$ in the two seasons of study. The interaction was not significant in both seasons.

The enhancement of fruiting as a result of using organic fertilizer in general and potassium addition in particular may be due to the organic materials which improve soil physiochemical conditions and reserved the sufficient amounts of $\mathrm{N}$ and $\mathrm{K}$. In addition, the release of much more less available elements ( $\mathrm{Fe}, \mathrm{Zn}$ and $\mathrm{Mn}$ ) as well as they increase the soil content of IAA and cytokenins (Li et al.,1998).Vigorous vegetative growth produced a high photosynthetic efficiency which causes an increment of reproductive growth and yield (Maksoud, 2000). The results of tree yield are in line with that of ElAdawy, (1987) ; Mordogan, et al., (2002) and Caetano, et al .,(2006) on fig; Abou - Taleb (2004) on pecan and Foud, et al., (2002)on citrus.

2-Fruit quality:

Average main fruit weight: Data concerning the effect of different organic sources and potassium addition on average main fruit weight during 2005 and 2006 seasons are presented in Table (7).

Regarding the specific organic manures, all the tested sources were significantly effective comparing with the control. The heaviest fruit weight was recorded when sheep manure was added, while the differences between values of trees fertilized with cattle and chicken manure were not significant compared with values of sheep manure in both seasons of study. Meanwhile, using $750 \mathrm{gm} \mathrm{K} \mathrm{K}_{2} \mathrm{O} /$ tree + foliar potassium $1 \%$ (K4) gave statistically higher records of main fruit weight in 2005 and 2006 seasons. 
Gowda, A. M.

6

1282 
J. Agric. Sci. Mansoura Univ., 32 (2), February, 2007

7 
Gowda, A. M.

Concerning the interaction effect, it was significant in the second season, whereas Sultani fig trees treated with sheep manure $+750 \mathrm{gm} \mathrm{K} \mathrm{K}_{2} \mathrm{O}$ / tree as soil addition and foliar potassium $1 \%$ increased significantly the fruit weight.

Fruit diameter, height and fruit moisture percentage: In this respect , the effect of organic sources and potassium addition are presented in Table (8).

As for the specific effect of different organic manure sources, data reveals obviously that, fruit diameter and fruit height significantly respond to organic manure source compared with the control . Whereas, sheep and cattle manure had the highest values followed by chicken manure in 2005 and 2006 seasons. On the other hand, the lowest values of fruit moisture percentage were recorded in fruits of the trees fertilized with sheep and cattle manures. Anyhow, the highest percentage of moisture in fruits were obtained from fruits of trees subjected to chicken manure and control and the differences were not significant in 2005 and 2006 seasons.

Referring to the specific effect of potassium addition, Table (8) also shows that, fruit diameter and height were significantly affected by the different potassium fertilization techniques with soil and / or foliar application in the two seasons of study. Meantime, Sultani fig trees fertilized with750 gm $\mathrm{K}_{2} \mathrm{O}$ / tree (soil) + foliar potassium $1 \%(\mathrm{~K} 4)$ produced the highest fruit diameter and height followed by $500 \mathrm{gm} \mathrm{K}_{2} \mathrm{O} /$ tree + foliar potassium $1 \%(\mathrm{~K} 3)$. The highest percentage of fruit moisture content was recorded from the treatment included foliar potassium $1 \%$ in both seasons (Table, 8 ) .

With regard to the effect of the interaction on fruit diameter and height, it was significant, while the same treatment didn't affect fruit moisture content in 2005 and 2006 seasons. The highest fruit diameter and height were obtained from trees fertilized with sheep manure and supplemented by 750 $\mathrm{gm} \mathrm{K}_{2} \mathrm{O} /$ tree + foliar potassium $1 \%(\mathrm{~K} 4)$ during both seasons. These findings were in agreement with those obtained by Mordogan, et al . , (2002) and Caetano, et al., (2006) on fig ; Abou -Taleb,(2004)on pecan .

The improvement of fruit quality ( fruit weight, diameter, height and fruit moisture content ) as a result of applying organic matter to soil is mainly due to the improvement in structure, essential elements, soils ability to hold water and nutrients as well as resist compacting and crusting (Madison et al., 1986). The positive effect of potassium fertilization may be due to its important role in promoting and enhancing the metabolic process during uptake, root activation, regulate water balance and translocation compounds which in turn increase the growth and reflects on yield and fruit quality (Najjar, 1985). Sen and Chaunan (1983) found that rising potassium rates increased the yield of pomegranate trees.

Total soluble solids (T.S.S.\%), total acidity (\%) and total sugars (\%) :

As for the effect of the investigated organic fertilizer, data in Table (9) show that, the fruits of sheep manure fertilized trees had the highest values of total soluble solids (T.S.S.\%) and total sugars. Moreover, cattle and sheep manure treatments gave the highest total soluble solids values compared to the control treatment in the $1^{\text {st }}$ season. In the contrast, in the $2^{\text {nd }}$ one, the differences of trees which fertilized with cattle, sheep and chicken manures were not significant compared with the control. 
J. Agric. Sci. Mansoura Univ., 32 (2), February, 2007

8

1285 
Gowda, A. M.

9

1286 
Regarding fruit total sugars content, the trees fertilized with cattle, sheep and chicken manures had insignificant values related to the control in 2005 season.

While, in 2006 season, the differences between the values of trees fertilized with cattle and chicken manures were not significant .

Concerning the response to potassium addition, it was so clear that fertilization with $750 \mathrm{gm} \mathrm{K} \mathrm{K}_{2} \mathrm{O}$ / tree + foliar potassium 1\% (K4) treatment was superior for raising fruit TSS and total sugars contents during both seasons. As for interaction effect, it was not significant in the first season. Sultani fig trees fertilized with sheep manure and (k4) exerted statistically the highest stimulate effect on fruit TSS and total sugars in the $2^{\text {nd }}$ one .

The three sources of organic manures had a significant effect on total acidity values of Sultani fig tree fruits compared with the control. On the contrary, the same character decreased significantly during 2005 and 2006 seasons when sheep manure was applied in the first season and cattle manure in the second one.

Meanwhile, the addition of potassium improved the acidity content of fruits, hence, the lowest acidity content was recorded when the trees fertilized with $500 \mathrm{gm} \mathrm{K} \mathrm{K}_{2} \mathrm{O} /$ tree + foliar potassium $1 \%(\mathrm{~K} 3)$ and $750 \mathrm{gm} \mathrm{K} \mathrm{K}_{2} \mathrm{O} /$ tree + foliar potassium $1 \%(\mathrm{~K} 4)$ in the two seasons of study .

In addition, total acidity responded significantly to the interaction between organic manure sources and potassium addition in both seasons. Application of cattle and sheep manures with (k4) treatment gave the pronounced effect on decreasing fruit total acidity content in the two studied seasons. The results are in line with those of El-Adawy, (1987) ; Mordogan, et al., (2002) and Caetano, et al ., (2006) on fig and Abd El-Naby et al., (2004) on citrus

\section{III- Leaf mineral composition .}

Data concerning the effect of organic and potassium addition on leaf $\mathrm{N}$, $\mathrm{P}$ and $\mathrm{K}$ contents during 2005 and 2006 seasons are presented in Table (10). Regarding the effect of organic manure sources, the highest nitrogen and phosphorus values were recorded in leaves of trees treated with sheep manure in both seasons. While, the differences between sheep and chicken manure on phosphorus content were not significant in both seasons. Leaf potassium content increased significantly due to the addition of chicken and sheep manure compared with the control.

As for potassium treatments effect, the highest level of nitrogen and phosphorus content was observed in leaves of the fertilized trees with 500 $\mathrm{gm} \mathrm{K}_{2} \mathrm{O} /$ tree + foliar sprayed with potassium $1 \%(\mathrm{~K} 3)$ followed by $750 \mathrm{gm}$ $\mathrm{K}_{2} \mathrm{O} /$ tree + foliar sprayed with potassium 1\% (K4) treatment in 2005 and 2006 seasons. Leaf potassium content was significantly increased by adding $750 \mathrm{gm} \mathrm{K} \mathrm{K}_{2} \mathrm{O} /$ tree + foliar potassium $1 \%$ (K4) in both seasons.

Concerning the interaction effect on N, P and K contents. Data reveals that Sultani fig trees received combination of chicken or sheep manure and $500 \mathrm{gm} \mathrm{K} \mathrm{K}_{2} \mathrm{O} /$ tree + foliar potassium $1 \%(\mathrm{~K} 3)$ induced the highest level of nitrogen and phosphorus in the $1^{\text {st }}$ season. While, sheep manure $+(k 3)$ gave the highest $\mathrm{N}$ content in the $2^{\text {nd }}$ one . 
Gowda, A. M.

10

1288 
The combination which included chicken manure and $750 \mathrm{gm} \mathrm{K}_{2} \mathrm{O} /$ tree + foliar sprayed with potassium $1 \%$ (K4) gave the highest values of leaf potassium content in 2005 and 2006 seasons. These results are in conformity with El-Adawy,(1987); Irget et al., (1999); Mordogan,et al., (2002) and Caetano, et al., (2006) on fig; Kassem and Marzouk, (2002) on grapevine; Abou -Taleb,(2004) on pecan and Abd El-Naby et al., (2004) on citrus.

The promotion in leaf mineral content due to organic fertilizers which improving the structure of soil, aeration and drainage, amount of water available and favorable conditions of root growth and nutrient absorption. On the other hand, the organic nitrogen added to the soil in the form of plant and animal residues is largely proteinceous in nature. Similar results were reported by Cook, (1982). Moreover, the improvement of leaf nutrients content as a result of potassium addition may be due to its active role in enhancing the absorption, translocation and accumulation of mineral contents in leaves (Hikal, 2000).

As a conclusion, sheep or cattle manure when supplemented with $500 \mathrm{gm}$ $\mathrm{K}_{2} \mathrm{O}$ / tree + foliar potassium at $1 \%$ can be recommended in potassium fertilization program to obtain higher yield and better fruit quality of fig trees (Sultani cv.) under the same conditions of this study.

\section{REFERENCES}

A.O.A.C.(1975). Official methods of analysis. Association of Official Analysis Chemist. Published by A.O.A.C. Washington, D.C.(U.S.A.).

Abdel- Kader,Hayat M. and S.M.Sabbah (2002). Effect of potassium fertilization on vegetative growth, yield, fruit quality and leaf mineral composition of some pomegranate cultivars. Minufiya J. Agric. Res. Vol. 27 (2): 337-353.

Abd El-Naby ,S. K.M. (2004). Response of Washington Navel orange trees growing on sandy soil to mixture of some organic fertilizers. Assiut J. of Agric. Sci. Vol. 35 (2): 215-235.

Abd El-Naby ,S. K.M.; Abd El- Moneim, Eman A.A. and A.S.E.AbdAllah (2004). Effect of source and date of organic manure application on growth, yield, fruit quality and mineral content of Washington Navel orange trees grown in sandy soil. Minufiya J. Agric. Res. Vol. 2 (29): 515-540.

Abou- Hussein S.D.; I.El- Oksha; T.El-Shorbagy and A.M.Gomaa (2002). Effect of cattle manure ,bio fertilizers and reducing mineral fertilizer on nutrient content and yield of potato plant. Egypt J. Hort. 29 (1): 99-115.

Abou-Taleb, Safia, A (2004). Effect of cattle manure and reducing mineral fertilizer on growth, fruit quality and nutrient content of pecan trees. Annals of Agric. Sc. Moshtohor, Vol. 42 (3) : 1197- 1214.

Caetano, L.C.S.; A.J. Cordeiro de Carvalho and J.M. Jasmim (2006). Preliminary report on yield productivity and mineral composition of the fig tree as a function of boron and cattle manure fertilization in Brazil. Fruits, 61: $341-349$.

Chapman, H.D. (1968). The mineral nutrition of citrus. Citrus Ind. Vol.II, Chap. 3: 127- 289. Univ. Calif., USA.

Chapman, H.D. and P.E.Pratt (1978).Methods of Analysis for Soils, Plants and Waters . Univ. of California, Div. Agric. Sci., priced pub 4034. 
Cook, G.W.(1982).Fertilizing for Maximum Yield . $3^{\text {rd }}$ ed. Granada Publishing Limited, pp. 465.

Duncan, D. B. (1955). Multiple range and multiple F. Tests biometrics, 11: 142.

El- Adawy, Samia A.F.(1987). Response of irrigated and non-irrigated Sultany fig trees grown in the Egyptian North Western Coast to soil and foliar fertilization.Ph.D.Thesis. Fac. Agric.Alex.Univ., Egypt

Ferguson, j.j ( 1994). Growth and yield of bearing and non- bearing citrus trees fertilized with fresh and processed chicken manure .Proc. of The Florida State Hort. Soc. 1994, $107: 29-32$.

Foud, Amera A. ; L.L.Khalil, Fekrya ;E.M.Abdallah and E.A.Shaban (2002). Studies on the effect of organic nitrogen and / or mineral nitrogen, phosphorus and potassium fertilizers on the yield and fruit quality of Washington Navel orange trees. Proc. Minia $1^{\text {st }}$ Conf. For Agric. \& Environ. Sci. , Minia, Egypt, March 25- 28.

Gamal,A.M. and M.A.Ragab (2003). Effect of organic manure source and its rate on growth, nutritional status of the trees and productivity of Balady Mandarin trees. Assiut J. of Agric. Sci. Vol. 34 (6): 253-264.

Haggag, Laila, F. (1996). Response of Picual olive trees in sandy soil to various forms of $\mathrm{N}$ fertilization ( organic and chemical ). Annals Agric. Sci., Ain Shams Univ., Cairo .41 (1): 313-319.

Hikal, A.R.F.(2000). Physiological studies on nutrition of Washington Navel orange trees. Ph.D.Thesis. Fac. Agric.Mansoura Univ., Egypt.

Irget, M.E.; S.Aydin; M.Oktay; M.Tutam; U.Aksoy and M.Nalbant (1999). Effects of foliar potassium nitrate and calcium nitrate application on nutrient content and fruit quality of fig . Improved crop quality by nutrient management .Kluwer Acdemic Publishers. Dordrecht ,Boston- London. 81-86.

Jackson, M.H. (1973). Soil Chemical Analysis. Prentice Hall. Inc. N.J. Privatle Limited and New Delhi.

Kassem ,H.A. and H.A.Marzouk (2002). Effect of organic and / or mineral nitrogen fertilization on the nutritional states, yield and fruit quality of Flam Seedless Grapevines grown in calcareous soil. J. Adv. Agric. Res., 7 (1): 117- 125.

Koo, R.C.J.(1985). Effect of nitrogen and potassium fertilization on winter injury of citrus trees. Pro. Fla. State Hort., 98:53-56.

Li, X.J.; S. F.Dong and Y.S. Liu (1998) .Determination of IAA and cytokinins in the soil with different oraginc manure for pot cultured apple. Plant Physiology Communications, 34(3):183-185.

Madison, F.;K. Kelling ; J. Peterson; I. Daniel; G.Jackson and L.Massie (1986).Managing manure and waste: Guidelines for applying manure to pasture and cropland in Wisconsin. Report A 3392. Madison: University of Wisconsin- Extension.

Maksoud, M.A. (2000).Response of growth and flowering of Manzanillo olive trees to different sorts of nutrient . Egypt J. of Hort. 27(4): 513583.

Mengel, K. and A.Kirkby .(1987). "Principles of plant nutrition" , $4^{\text {th }}$ Ed., International Potash Institute, Norblafen- Bern, Switzerland.

Mordogan,N.; H.Hakerlerler; S.Ceylan; S.Aydin; B.Yagmur and U.Aksoy (2002). Effect of organic fertilization on fig leaf nutrients and fruit quality. International Conference On Sustainable Land Use and Management, 2002. Canakkale, Turkey.

Murphy, J. and J.P.Riley (1962). A modified single solution for the determination of phosphate natural water. Anal. Chem. Acta., $27: 31$ 36. 
Nijjar, G.S. (1985).Nutrition of fruit trees .Kaalyani Puplishers, New Delhi, India. pp. 10- 52.

Sen,N.L. and K.S.Chauhan (1983).Effect of differential NPK fertilization on physico- chemical characters of pomegranate. Punjab - Hort. J.,23: $1 / 2,59-63$.

Snedecor, G.W. and W.G. Cochran (1980). Statistical methods. $7^{\text {th }}$ ed. lowa State Univ. Press, Ames, lowa, U.S.A. pp . 507.

Wilde, S.A.;R.B. Corey; J.G.Lyer and G.K.Voigt. (1985).Soil and Plant Analysis for Tree culture. Oxford and IBH Publishing Co., New Delhi India.

Youssef,A.H.;A.H.El- Fouly ; M.S.Youssef and S.A.Mohamadien (2001). Effect of using organic and chemical fertilizers in fertigation system on yield and fruit quality of potato plants (Solanum turerosum L. ). Resent Technologies in Agriculture.Proc. Of the $2^{\text {nd }}$ congress. Vol.(1): $: 79-94$.

Zhou, X.W. ;Z.Y.Li; B.Lu; X.N.Chen; L.J.Xu; Y.W.Yi; X.W.Zhou;Z.Y.Li; B.Lu; X.N.Chen; L.J.Xu and Y.W.Yi (2001).Study on the improvement of the soil of the newly established orchard on the reclaimed purple soil .J. of Fruit Sci. $18: 1,15-19$.( C.F. CAB Abst. 1001 - 7364).

تثأثير بعض التين السلطاني مادة العضوية و إضـافة البوتاسيوم على النمو والمحصول وجوده قسم بحوث الزيتون وفاكها المناطق شبه الجافةـ معهد بحوث البساتين- مركز البحوث الزراعية ـ

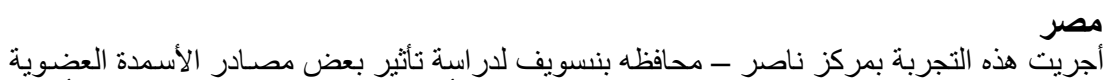

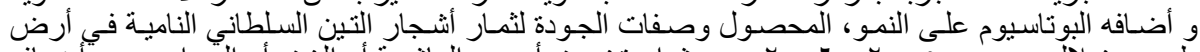

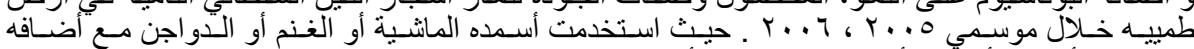

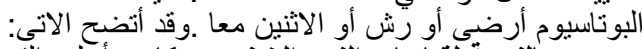

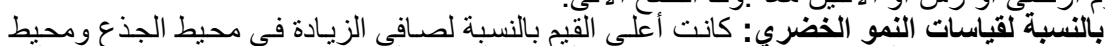

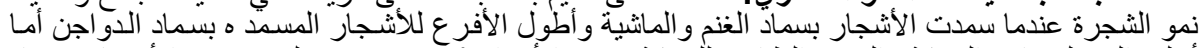

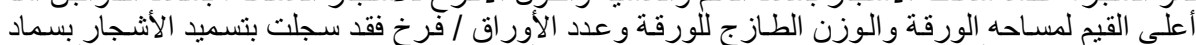

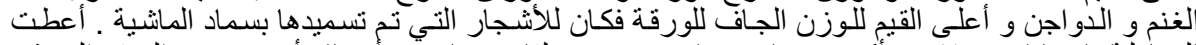

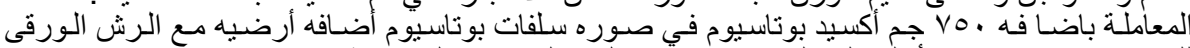

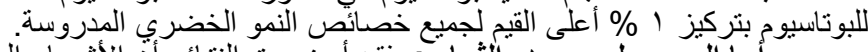

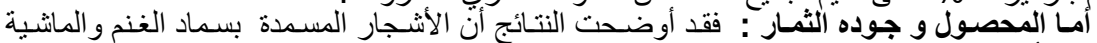

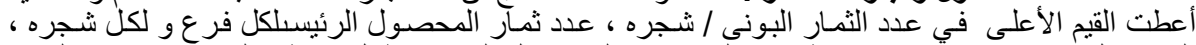

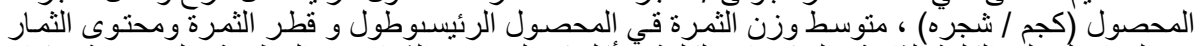

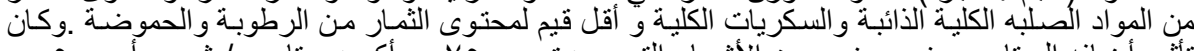

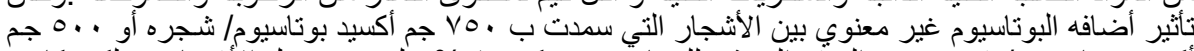

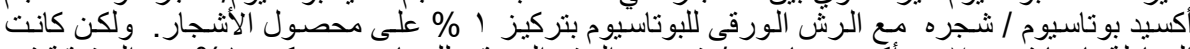

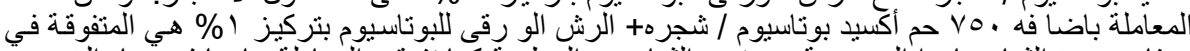

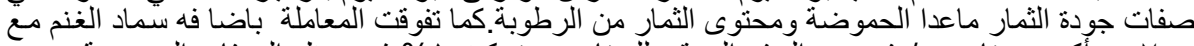

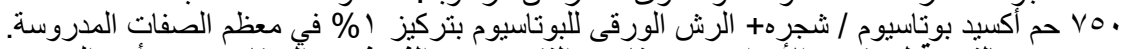

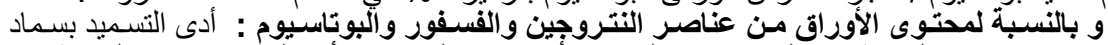

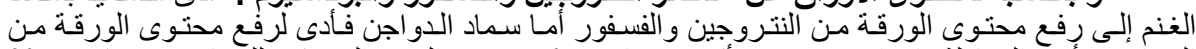

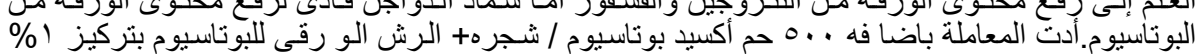

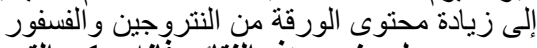

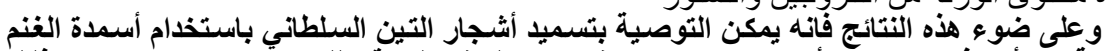

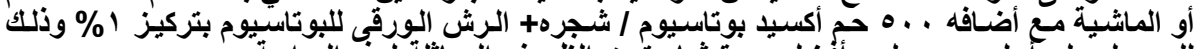

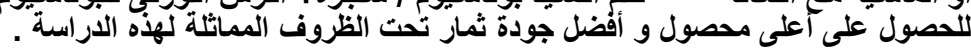


Gowda, A. M. 
J. Agric. Sci. Mansoura Univ., 32 (2): 1273 - 1291, 2007 
Table (4) : Effect of different organic manure sources and potassium addition on net increase in trunk circumference (cm), canopy circumference $(\mathrm{m})$ and shoot length $(\mathrm{cm})$ during 2005 and 2006 seasons.

\begin{tabular}{|c|c|c|c|c|c|c|c|c|c|c|c|c|c|c|c|c|}
\hline \multirow{2}{*}{$\begin{array}{c}\text { Charact } \\
\text { Treat. }\end{array}$} & \multicolumn{5}{|c|}{ Net increase in trunk circumference (m) } & \multicolumn{6}{|c|}{ Canopy circumference (m) } & \multicolumn{5}{|c|}{ Shoot length (cm) } \\
\hline & $\begin{array}{c}\text { Cattle } \\
\text { manure }\end{array}$ & $\begin{array}{l}\text { Sheep } \\
\text { manure }\end{array}$ & $\begin{array}{l}\text { Chicken } \\
\text { manure }\end{array}$ & Control & Mean & \begin{tabular}{|c|} 
Cattle \\
manure
\end{tabular} & $\begin{array}{l}\text { Sheep } \\
\text { manure }\end{array}$ & $\begin{array}{l}\text { Chicken } \\
\text { manure }\end{array}$ & Control & Mear & & $\begin{array}{c}\text { Cattle } \\
\text { manure }\end{array}$ & $\begin{array}{c}\text { Sheep } \\
\text { manure }\end{array}$ & $\begin{array}{l}\text { Chicken } \\
\text { manure }\end{array}$ & Control & Mean \\
\hline & \multicolumn{16}{|c|}{2005 season } \\
\hline K1 & $6.04^{\star *}$ & 5.77 & 5.21 & 4.73 & $5.44 \mathrm{D}$ & 9.4 & 9.6 & 9.8 & 8.1 & 9.2 & C & 68.45 & 69.37 & 72.49 & 6360 & $68.48 \mathrm{D}$ \\
\hline K2 & $\frac{0.04}{6.32}$ & $\frac{1.11}{6.07}$ & $\frac{.61}{5.64}$ & $\frac{4.15}{5.08}$ & $\mid \begin{array}{ll}\mid 0.44 & \mathrm{~L} \\
5.78 & \mathrm{C}\end{array}$ & $\frac{. .4}{10.4}$ & 11.2 & $\frac{5.0}{10.4}$ & 8.7 & \begin{tabular}{|l|l|}
10.2 \\
10.2
\end{tabular} & B & $\frac{00.4 \mathrm{U}}{72.44}$ & 76.61 & $\frac{76.40}{76.02}$ & $\frac{0.00}{64.00}$ & $72.27 \mathrm{C}$ \\
\hline K 3 & 6.64 & 6.20 & 5.58 & 5.90 & $\mid \begin{array}{ll}6.08 & B\end{array}$ & 10.4 & 11.9 & 10.7 & 9.2 & 10.6 & B & 73.77 & 77.20 & 82.02 & 64.99 & $74.50 \mathrm{~B}$ \\
\hline \multirow{2}{*}{$\begin{array}{l}\text { K } \\
K 55\end{array}$} & 6.97 & 6.74 & 6.00 & 5.88 & $6.40 \mathrm{~A}$ & 11.9 & 13.0 & 11.6 & 9.4 & 11.5 & $\mathbf{A}$ & 76.57 & 76.73 & 83.47 & 69.54 & $76.58 \mathrm{~A}$ \\
\hline & 5.66 & 5.24 & 4.71 & 4.08 & $4.92 \mathrm{E}$ & 9.0 & 9.5 & 9.1 & 7.6 & 8.8 & C & 65.74 & 68.98 & 70.93 & 56.38 & $65.51 \mathrm{E}$ \\
\hline Mean & \multicolumn{5}{|c|}{\begin{tabular}{|ll|ll|ll|ll|}
6.33 & $\mathrm{~A}^{*}$ & 6.00 & $\mathrm{~A}$ & 5.43 & $\mathrm{~B}$ & 5.13 & $\mathrm{~B}$ \\
\end{tabular}} & $10.2 \mathrm{~B}$ & $11.0 \mathrm{~A}$ & $10.3 \mathrm{~B}$ & $8.6 \mathrm{C}$ & & & $71.39 \mathrm{C}$ & $73.78 \mathrm{~B}$ & $76.99 \mathrm{~A}$ & $63.70 \mathrm{D}$ & \\
\hline & \multicolumn{16}{|c|}{2006 season } \\
\hline K 1 & 6.32 & 6.24 & 5.72 & 4.79 & $\begin{array}{lll}5.77 & C\end{array}$ & 13.2 & 14.2 & 12.0 & 11.2 & 12.7 & c 7 & $72.48 \mathrm{gh}$ & 78.48 & 80.66 & 67.58 & $74.80 \mathrm{C}$ \\
\hline K 2 & 6.70 & 6.64 & 6.28 & 5.28 & $6.23 \mathrm{~B}$ & 15.9 & 16.2 & 13.3 & 12.7 & 14.5 & B & $\begin{array}{l}78.13 \\
\text { def }\end{array}$ & $80.24 \mathrm{de}$ & $84.79 \mathrm{bc}$ & $73.15 \mathrm{gh}$ & 79.08 B \\
\hline K 3 & 7.16 & 6.88 & 5.94 & 5.82 & $6.45 \mathrm{AB}$ & 14.8 & 15.6 & 13.7 & 12.5 & 14.2 & B 7 & $79.10 \mathrm{de}$ & $\begin{array}{l}82.35 \\
\text { bcd }\end{array}$ & $84.86 \mathrm{bc}$ & $71.00 \mathrm{hi}$ & $79.33 \mathrm{~B}$ \\
\hline K 4 & 7.11 & 7.14 & 6.22 & 5.90 & $6.59 \mathrm{~A}$ & 16.7 & 17.1 & 15.1 & 13.3 & 15.6 & $\mathbf{A}$ & $86.87 \mathrm{~b}$ & $85.85 \mathrm{~b}$ & $94.33 \mathrm{a}$ & $\begin{array}{l}76.34 \\
\text { ffa }\end{array}$ & $85.85 \mathrm{~A}$ \\
\hline K5 & 5.79 & 5.71 & 5.70 & 4.54 & $5.44 \mathrm{D}$ & 11.4 & 13.5 & 11.4 & 10.1 & 11.6 & D & $\begin{array}{l}73.99 \\
\text { fgh }\end{array}$ & $72.93 \mathrm{gh}$ & $\begin{array}{l}74.33 \\
\text { fgh }\end{array}$ & $59.62 j$ & $70.22 \mathrm{D}$ \\
\hline Mean & $6.62 \mathrm{~A}$ & \begin{tabular}{|ll}
$6.52 \mathrm{~A}$ \\
\end{tabular} & $\mid \begin{array}{ll}5.97 & B\end{array}$ & $5.27 \mathrm{C}$ & & $14.4 \mathrm{~B}$ & $15.3 \mathrm{~A}$ & $\mid \begin{array}{ll}13.1 & C\end{array}$ & $12.0 \mathrm{D}$ & & & $78.11 \mathrm{C}$ & 79.97 B & $83.79 \mathrm{~A}$ & $69.54 \mathrm{D}$ & \\
\hline
\end{tabular}

Means having ${ }^{*}$ the same letters or ${ }^{* *}$ not having letters are not significantly differ at $5 \%$ level. 
Table (5) : Effect of different organic manure sources and potassium addition on leaf area (cm) ${ }^{2}$, leaf fresh and dry weight (gm) during 2005 and 2006 seasons.

\begin{tabular}{|c|c|c|c|c|c|c|c|c|c|c|c|c|c|c|c|}
\hline \multirow{2}{*}{$\begin{array}{c}\text { Characteri } \\
\text { stics } \\
\text { Treat. } \\
\end{array}$} & \multicolumn{5}{|c|}{ Leaf area $(\mathrm{cm})^{2}$} & \multicolumn{5}{|c|}{ Leaf fresh weight (gm) } & \multicolumn{5}{|c|}{ Leaf dry weight (gm) } \\
\hline & \begin{tabular}{|c|} 
Cattle \\
manure
\end{tabular} & \begin{tabular}{|c|} 
Sheep \\
manure
\end{tabular} & $\begin{array}{l}\text { Chicken } \\
\text { manure }\end{array}$ & Control & Mean & \begin{tabular}{|c|} 
Cattle \\
manure
\end{tabular} & \begin{tabular}{|c|} 
Sheep \\
manure
\end{tabular} & $\begin{array}{l}\text { Chicken } \\
\text { manure }\end{array}$ & Control & Mean & \begin{tabular}{|c|} 
Cattle \\
manure
\end{tabular} & $\begin{array}{c}\text { Sheep } \\
\text { manure }\end{array}$ & \begin{tabular}{|l|}
$\begin{array}{l}\text { Chicken } \\
\text { manure }\end{array}$ \\
\end{tabular} & Control & Mean \\
\hline & \multicolumn{15}{|c|}{2005 season } \\
\hline K 1 & 354.9 & 418.8 & 342.0 & 304.0 & $354.9 \mathrm{C}$ & 15.56 & 16.36 & 17.07 & 13.45 & $15.61 \mathrm{C}$ & $7.63 \mathrm{ghi}$ & $7.40 \mathrm{hi}$ & $6.97 \mathrm{hij}$ & 5.76 & $6.94 \mathrm{D}$ \\
\hline K 2 & 379.9 & 420.9 & 365.9 & 322.3 & $\begin{array}{c}372.2 \\
\text { BC }\end{array}$ & 17.89 & 17.90 & 18.07 & 14.93 & $17.20 \mathrm{~B}$ & 9.03 cde & efg & $7.83 \mathrm{fgh}$ & 6.72 ilk & $7.98 \mathrm{C}$ \\
\hline K 3 & 415.3 & 441.1 & 385.6 & 322.4 & $\begin{array}{l}391.1 \\
A B\end{array}$ & 18.20 & 19.52 & 19.00 & 15.13 & $17.96 \mathrm{~B}$ & $9.52 \mathrm{~cd}$ & $11.21 \mathrm{~b}$ & $8.68 \mathrm{def}$ & $6.41 \mathrm{jkl}$ & $8.96 \mathrm{~B}$ \\
\hline K 4 & 432.8 & 449.8 & 418.9 & 351.0 & 413.1 A & 19.27 & 20.64 & 20.48 & 16.63 & $19.26 \mathrm{~A}$ & $10.99 \mathrm{~b}$ & $12.46 \mathrm{a}$ & $\begin{array}{|ll|}9.59 & \mathrm{c} \\
\end{array}$ & $7.67 \mathrm{gh}$ & $10.18 \mathrm{~A}$ \\
\hline 5 & 339.9 & 371.4 & 433.9 & 288.9 & $\begin{array}{r}35 \\
\mathrm{~B}\end{array}$ & 14.31 & 15.02 & 15.50 & 25 & 14.27 D & $6.89 \mathrm{hij}$ & $7.63 \mathrm{ghi}$ & $6.38 \mathrm{jkl}$ & $5.93 \mathrm{kl}$ & $6.71 \mathrm{D}$ \\
\hline \multirow[t]{2}{*}{ Mean } & $34.6 \mathrm{~B}^{*}$ & $420.4 \mathrm{~A}$ & $389.3 \mathrm{~B}$ & $317.7 \mathrm{C}$ & & $17.05 \mathrm{~B}$ & $\begin{array}{c}17.89 \\
A B\end{array}$ & $18.03 \mathrm{~A}$ & 14 & & $8.81 \mathrm{~B}$ & $9.41 \mathrm{~A}$ & $\begin{array}{|ll|}7.89 & \mathrm{C}\end{array}$ & $6.50 \mathrm{D}$ & \\
\hline & \multicolumn{15}{|c|}{2006 season } \\
\hline K 1 & $334.7 \mathrm{de}$ & $321.24 \mathrm{ef}$ & f 322.5 ef & $302.8 \mathrm{fg}$ & $0.3 \mathrm{D}$ & $16.07 \mathrm{fg}$ & $\begin{array}{l}18.30 \\
\text { cde }\end{array}$ & $0 \mathrm{bc}$ & $88 \mathrm{fg}$ & $64 \mathrm{D}$ & 8.56 ef & $8.22 \mathrm{efg}$ & $7.73 \mathrm{fgh}$ & 6.91 & $7.85 \mathrm{C}$ \\
\hline K 2 & $\begin{array}{l}342.9 \\
\text { cde }\end{array}$ & 327.8 ef & $\begin{array}{c}364.3 \\
b c\end{array}$ & 316.7 ef & $337.9 \mathrm{C}$ & $19.55 \mathrm{bc}$ & $20.24 \mathrm{~b}$ & $20.26 b$ & $18.38 \mathrm{~cd}$ & $19.61 \mathrm{~B}$ & $\begin{array}{c}10.03 \\
\text { bcd }\end{array}$ & $9.88 \mathrm{~cd}$ & 8.61 ef & $7.68 \mathrm{fgh}$ & $9.05 \mathrm{~B}$ \\
\hline K 3 & $371.3 \mathrm{ab}$ & $\begin{array}{c}357.1 \\
\text { bcd }\end{array}$ & $374.2 \mathrm{ab}$ & $304.8 \mathrm{fg}$ & $351.8 \mathrm{~B}$ & $\begin{array}{c}17.36 \\
\text { def }\end{array}$ & $19.67 \mathrm{bc}$ & $20.51 \mathrm{~b}$ & $16.55 \mathrm{fg}$ & $18.52 \mathrm{C}$ & $10.29 \mathrm{bc}$ & $10.88 \mathrm{~b}$ & $9.22 \mathrm{de}$ & $7.28 \mathrm{gh}$ & $9.42 \mathrm{~B}$ \\
\hline K 4 & 394. & $375.9 \mathrm{ab}$ & $396.3 \mathrm{a}$ & $329.5 \mathrm{ef}$ & $374.0 \mathrm{~A}$ & $22.92 \mathrm{a}$ & $21.89 \mathrm{a}$ & $22.25 \mathrm{a}$ & 19 & A & a & 14 & $\begin{array}{c}10.00 \\
\text { bcd }\end{array}$ & 8.50 ef & 11. \\
\hline K 5 & 284 & $306.3 \mathrm{fg}$ & $318.1 \mathrm{ef}$ & $\begin{array}{l}3.0 \\
h\end{array}$ & $295.4 \mathrm{E}$ & $15.70 \mathrm{~g}$ & $16.42 \mathrm{fg}$ & $\begin{array}{c}17.01 \\
\text { efg }\end{array}$ & $14.07 \mathrm{~h}$ & $15.80 \mathrm{E}$ & 8.44 ef & $7.88 \mathrm{fgh}$ & $7.58 \mathrm{fgh}$ & 5.85 & $7.44 \mathrm{C}$ \\
\hline Mean & 345.5AB & $337.7 \mathrm{~B}$ & $355.1 \mathrm{~A}$ & 305.4 C & & 18.32BB & 19.30AA & $9.89 \mathrm{~A}$ & $17.06 \mathrm{C}$ & & $10.45 \mathrm{~A}$ & $10.24 \mathrm{~A}$ & $8.63 \mathrm{~B}$ & $7.25 \mathrm{C}$ & \\
\hline
\end{tabular}

Means having ${ }^{*}$ the same letters or ${ }^{* \star}$ not having letters are not significantly differ at $5 \%$ level. 


\section{Gowda, A. M.}

Table (6) : Effect of different organic manure sources and potassium addition on number of leaves / shoot, number of breba fruits / tree and number of main fruits/ shoot during 2005 and 2006 seasons.

\begin{tabular}{|c|c|c|c|c|c|c|c|c|c|c|c|c|c|c|c|}
\hline \multirow{2}{*}{$\begin{array}{c}\begin{array}{c}\text { Characteri } \\
\text { stics }\end{array} \\
\text { Treat. } \\
\end{array}$} & \multicolumn{5}{|c|}{ Number of leaves / shoot } & \multicolumn{5}{|c|}{ Number of breba fruits/ tree } & \multicolumn{5}{|c|}{ Number of main fruits / shoot } \\
\hline & \begin{tabular}{|c|} 
Cattle \\
manure
\end{tabular} & \begin{tabular}{|c|} 
Sheep \\
manure
\end{tabular} & $\begin{array}{l}\text { Chicken } \\
\text { manure }\end{array}$ & Control & Mean & \begin{tabular}{|c|} 
Cattle \\
manure
\end{tabular} & $\begin{array}{c}\text { Sheep } \\
\text { manure }\end{array}$ & $\begin{array}{l}\text { Chicken } \\
\text { manure }\end{array}$ & Control & Mean & \begin{tabular}{|c|} 
Cattle \\
manure
\end{tabular} & \begin{tabular}{c|} 
Sheep \\
manure
\end{tabular} & $\begin{array}{l}\text { Chicken } \\
\text { manure }\end{array}$ & Control & Mean \\
\hline & \multicolumn{15}{|c|}{2005 season } \\
\hline K 1 & 11.72 & 13.41 & 14.76 & 10.32 & $12.55 \mathrm{D}$ & 12.7 & 12.0 & 10.0 & 8.7 & $10.8 \mathrm{D}$ & 12.93 & 13.48 & 13.10 & 12.17 & $12.92 \mathrm{C}$ \\
\hline K2 & 12.91 & 14.07 & 15.74 & 11.90 & $13.65 \mathrm{C}$ & 14.7 & 15.0 & 13.0 & 9.3 & $13.0 \mathrm{C}$ & 14.04 & 14.21 & 13.28 & 13.15 & $13.67 \mathrm{~B}$ \\
\hline K 3 & 13.72 & 15.33 & 16.71 & 12.20 & $14.49 \mathrm{~B}$ & 18.0 & 19.7 & 14.3 & 0 & $15.5 \mathrm{~B}$ & 14.43 & 16.26 & 14.40 & 13.40 & $14.62 \mathrm{~A}$ \\
\hline K 4 & 15.05 & 16.38 & 17.65 & 12.89 & $15.49 \mathrm{~A}$ & 23.7 & 24.7 & 15.7 & 11.7 & $18.9 \mathrm{~A}$ & 15.00 & 16.53 & 14.57 & 13.70 & 14.9 \\
\hline K5 & 10.11 & 12.01 & 13.39 & 8.96 & $11.12 \mathrm{E}$ & 15.0 & 13.7 & 10.0 & 7.0 & $11.4 \mathrm{CD}$ & 12.09 & 13.24 & 13.07 & 11.80 & $12.55 \mathrm{C}$ \\
\hline \multirow[t]{2}{*}{ Mean } & $12.70 \mathrm{C}$ & $14.24 \mathrm{~B}$ & $15.65 \mathrm{~A}$ & $11.25 \mathrm{D}$ & & $16.8 A^{*}$ & $\begin{array}{ll}17.0 & \mathrm{~A}\end{array}$ & $12.6 \mathrm{~B}$ & $9.3 \mathrm{C}$ & & $13.70 \mathrm{~B}$ & $14.74 \mathrm{~A}$ & $13.69 \mathrm{~B}$ & $12.84 \mathrm{C}$ & \\
\hline & \multicolumn{15}{|c|}{2006 season } \\
\hline K 1 & $\begin{array}{l}13.47 \\
\text { gh }\end{array}$ & $\begin{array}{c}14.84 \\
e\end{array}$ & $\begin{array}{c}14.98 \\
e\end{array}$ & $\begin{array}{c}13.02 \\
\mathrm{hi}\end{array}$ & $14.08 \mathrm{D}$ & $15.3 \mathrm{gh}$ & $16.7 \mathrm{fg}$ & $16.0 \mathrm{gh}$ & $\begin{array}{r}17.7 \\
d-g\end{array}$ & $16.4 \mathrm{CD}$ & 14.10 & 14.87 & 14.34 & 12.82 & $14.03 \mathrm{C}$ \\
\hline K 2 & $\begin{array}{l}14.48 \\
\text { ef }\end{array}$ & $\begin{array}{c}15.89 \\
d\end{array}$ & $\begin{array}{c}15.96 \\
d\end{array}$ & $\begin{array}{c}14.28 \\
\text { ef }\end{array}$ & $15.15 \mathrm{C}$ & $\begin{array}{r}18.3 \\
\mathrm{C}-\mathrm{g}\end{array}$ & $\begin{array}{r}20.0 \\
b-f\end{array}$ & $\begin{array}{r}17.7 \\
d-g\end{array}$ & $12.7 \mathrm{~h}$ & $17.2 \mathrm{C}$ & 14.95 & 15.21 & 14.60 & 13.25 & $\begin{array}{c}14.50 \\
\mathrm{BC}\end{array}$ \\
\hline K 3 & $\begin{array}{l}16.63 \\
\text { cd }\end{array}$ & $\begin{array}{c}16.6 \\
\mathrm{~cd}\end{array}$ & $\begin{array}{l}17.07 \\
\text { c }\end{array}$ & $\begin{array}{c}16.09 \\
d\end{array}$ & $16.60 \mathrm{~B}$ & $\begin{array}{r}20.7 \\
\mathrm{a}-\mathrm{e}\end{array}$ & $21.7 \mathrm{abc}$ & $\begin{array}{r}18.0 \\
\mathrm{c}-\mathrm{g}\end{array}$ & $15.7 \mathrm{gh}$ & $19.0 \mathrm{~B}$ & 16.39 & 16.44 & 15.61 & 13.47 & $15.48 \mathrm{~A}$ \\
\hline K 4 & $\begin{array}{l}19.09 \\
a\end{array}$ & $\begin{array}{c}18.18 \\
b\end{array}$ & $\begin{array}{c}18.23 \\
b\end{array}$ & $\begin{array}{c}16.54 \\
\mathrm{~cd}\end{array}$ & $18.01 \mathrm{~A}$ & $24.3 \mathrm{a}$ & $22.3 \mathrm{ab}$ & $\begin{array}{r}21.3 \\
a-d\end{array}$ & $\begin{array}{r}20.3 \\
b-f\end{array}$ & $22.1 \mathrm{~A}$ & 16.51 & 16.30 & 16.29 & 14.29 & $15.85 \mathrm{~A}$ \\
\hline K 5 & $\begin{array}{c}12.34 \\
i\end{array}$ & $\begin{array}{c}13.80 \\
\mathrm{fg}\end{array}$ & $\begin{array}{c}13.97 \\
\mathrm{fg}\end{array}$ & $\begin{array}{c}11.0 \\
j\end{array}$ & $12.78 \mathrm{E}$ & 17.3 efg & $\begin{array}{r}18.0 \\
\mathrm{C}-9 \\
\end{array}$ & $16.0 \mathrm{gh}$ & 8.7 & $15.0 \mathrm{D}$ & 13.62 & 14.53 & 13.95 & 11.70 & $13.45 \mathrm{D}$ \\
\hline Mean & $15.20 \mathrm{~B}$ & $\begin{array}{c}15.86 \\
A B\end{array}$ & $16.04 \mathrm{~A}$ & $14.19 \mathrm{C}$ & & $19.2 \mathrm{~A}$ & $19.7 \mathrm{~A}$ & $17.8 \mathrm{~B}$ & $15.0 \mathrm{C}$ & & $15.11 \mathrm{AB}$ & $15.47 \mathrm{~A}$ & $14.96 \mathrm{~B}$ & $13.11 \mathrm{C}$ & \\
\hline
\end{tabular}

Means having * the same letters or ${ }^{* *}$ not having letters are not significantly differ at $5 \%$ level. 
Table (7) : Effect of different organic manure sources and potassium addition on number of main fruits / tree, fruit weight (gm) and yield (kg / tree) during 2005 and 2006 seasons.

\begin{tabular}{|c|c|c|c|c|c|c|c|c|c|c|c|c|c|c|c|}
\hline \multirow{2}{*}{\begin{tabular}{|c|}
$\begin{array}{c}\text { Characteri } \\
\text { stics }\end{array}$ \\
Treat. \\
\end{tabular}} & \multicolumn{5}{|c|}{ Number of main fruits/ tree } & \multicolumn{5}{|c|}{ Fruit weight (gm) } & \multicolumn{5}{|c|}{ Yield (kg / tree) } \\
\hline & $\begin{array}{c}\text { Cattle } \\
\text { manure }\end{array}$ & \begin{tabular}{|c|} 
Sheep \\
manure
\end{tabular} & $\begin{array}{l}\text { Chicken } \\
\text { manure }\end{array}$ & Control & Mean & \begin{tabular}{|c|} 
Cattle \\
manure
\end{tabular} & \begin{tabular}{|c|} 
Sheep \\
manure
\end{tabular} & \begin{tabular}{|l|} 
Chicken \\
manure
\end{tabular} & Control & Mean & \begin{tabular}{|c|} 
Cattle \\
manure
\end{tabular} & \begin{tabular}{|c|} 
Sheep \\
manure
\end{tabular} & $\begin{array}{l}\text { Chicken } \\
\text { manure }\end{array}$ & Control & Mean \\
\hline & \multicolumn{15}{|c|}{2005 season } \\
\hline K 1 & 778.3 & 803.7 & 741.7 & 493.3 & 704.3 C & 45.40 & 46.8 & 46.90 & 38.03 & $44.28 \mathrm{C}$ & 35.30 & 37.61 & 4.74 & 8. & $31.60 \mathrm{C}$ \\
\hline K2 & 842.7 & 890.3 & 812.0 & 571.7 & $779.2 \mathrm{~B}$ & 47.07 & 51.30 & 8.70 & 90 & $\mathrm{~B}$ & 39.68 & 44.46 & 39.54 & \multirow{2}{*}{\multicolumn{2}{|c|}{\begin{tabular}{|l|l|}
24.17 & $38.01 \mathrm{AB}$ \\
\end{tabular}}} \\
\hline K 3 & 864.3 & 908.3 & 805.7 & 584.3 & $\begin{array}{c}790.7 \\
A B\end{array}$ & 48.27 & 52.57 & 47.63 & 41.37 & $47.46 \mathrm{~B}$ & 41.72 & 47.75 & 3838 & & \\
\hline $\mathrm{K} 4$ & 893.7 & 905.3 & 87 & & $817.8 \mathrm{~A}$ & 49.6 & 53. & 49. & & & 44.39 & 48.43 & 43.62 & 25.11 & 42.02A \\
\hline & 775.3 & 762.3 & 641.7 & & & 44.77 & 44.63 & & & & 34.71 & 34.02 & 28.93 & 17.14 & \\
\hline Mean & $830.9 \mathrm{~A}^{*}$ & $854.0 \mathrm{~A}$ & $774.8 \mathrm{~B}$ & $543.5 \mathrm{C}$ & & 47.03 B & $49.76 \mathrm{~A}$ & 47.67 B & 39.7 & & $9.16 \mathrm{~B}$ & 42.45A & $7.04 \mathrm{~B}$ & $1.72 \mathrm{C}$ & \\
\hline & \multicolumn{15}{|c|}{2006 season } \\
\hline K 1 & 704.0 & 816.0 & 702.3 & 614.7 & $709.3 \mathrm{C}$ & $\begin{array}{l}45.70 \\
\text { efg }\end{array}$ & 47.2 & $46.40 \mathrm{~d}-\mathrm{g}$ & 40.67 & $45.01 \mathrm{C}$ & 2.18 & 8.51 & 61 & 24.98 & $32.07 \mathrm{C}$ \\
\hline K 2 & 780.3 & 877.7 & 764.3 & 677.0 & $774.8 \mathrm{~B}$ & $\begin{array}{l}50.53 \\
\text { defg }\end{array}$ & $49.83 \mathrm{bc}$ & $49.33 \mathrm{~cd}$ & 43.33 & $6 \mathrm{~B}$ & 39.40 & 43.75 & 37.70 & 29.32 & 37.54B \\
\hline K 3 & 856.7 & 885.0 & 804.7 & 728.0 & $\begin{array}{c}818.6 \\
A B\end{array}$ & $55.03 \mathrm{de}$ & $57.57 \mathrm{~b}$ & $\begin{array}{l}51.83 \\
\text { def }\end{array}$ & $45.90 \mathrm{hi}$ & $52.58 \mathrm{~B}$ & 14 & 0.95 & 41.71 & 33.42 & $40.69 \mathrm{~A}$ \\
\hline K4 & 876.0 & 901.0 & 823.0 & 747.0 & $836.8 \mathrm{~A}$ & $58.47 \mathrm{bc}$ & $58.50 \mathrm{a}$ & $54.40 \mathrm{~b}$ & $51.50 \mathrm{gh}$ & $55.72 \mathrm{~A}$ & 51.23 & 52.70 & 44.71 & 38.48 & 46.78A \\
\hline K 5 & 703.7 & 706.0 & 670.3 & 562.7 & $660.7 \mathrm{D}$ & $47.23 \mathrm{fg}$ & $46.13 \mathrm{fg}$ & $\begin{array}{l}45.23 \\
\text { efg }\end{array}$ & $37.07 \mathrm{j}$ & 43.92 D & & 32.60 & & & $29.25 C$ \\
\hline Mean & $784.2 \mathrm{~B}$ & $837.1 \mathrm{~A}$ & $752.9 \mathrm{C}$ & 665.9 D & & 51.39 B & $51.86 \mathrm{~A}$ & 49.44 B & $43.69 \mathrm{C}$ & & 40.63B & $43.70 \mathrm{~A}$ & 37.41C & \begin{tabular}{|l|}
$29.41 \mathrm{D}$ \\
\end{tabular} & \\
\hline
\end{tabular}

Means having ${ }^{*}$ the same letters or ${ }^{* \star}$ not having letters are not significantly differ at $5 \%$ level. 


\section{Gowda, A. M.}

Table (8) : Effect of different organic manure sources and potassium addition on fruit diameter (cm), fruit height (cm) and fruit water content (\%)

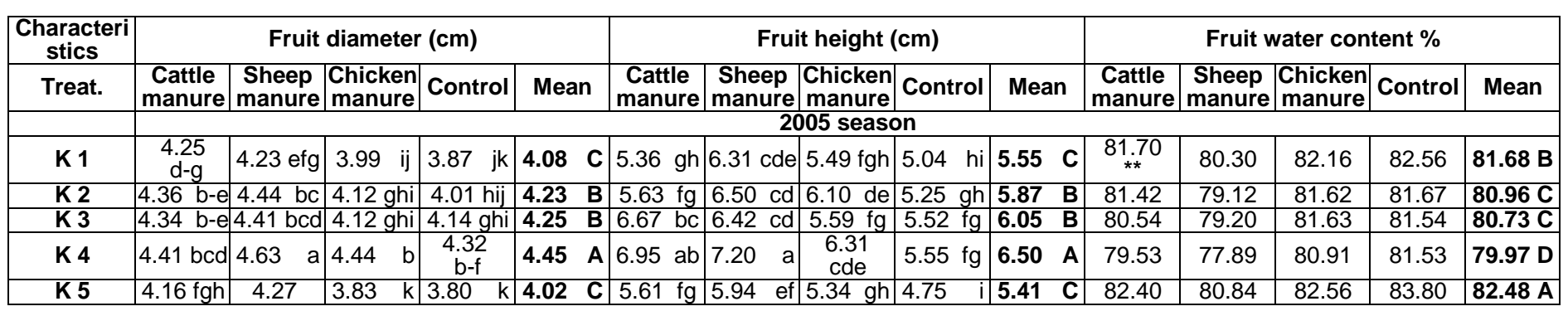

during 2005 and 2006 seasons. 


\begin{tabular}{|c|c|c|c|c|c|c|c|c|c|c|c|c|c|c|c|c|c|c|c|}
\hline Mean & & C-g & & $403 \mathrm{C}$ & & & & & & & & & & & $8112 \mathrm{~B}$ & & & & \\
\hline Iviean & 31 & $14.40 \quad \mathrm{~A}$ & $4.10 \mathrm{C}$ & $4.03 \quad \mathrm{C}$ & & .04 & & 0.48 & & $006 \mathrm{se}$ & easo & $\begin{array}{ll}5.22 & C \\
\text { on }\end{array}$ & & & $81.12 \mathrm{~B}$ & $19.41 \mathrm{C}$ & $81.84 \mathrm{~A}$ & $82.22 \mathrm{~A}$ & \\
\hline K 1 & 4.48 def & 4.49 def & $\begin{array}{c}4.33 \\
f-i\end{array}$ & $4.19 \mathrm{ijk}$ & $4.37 \mathrm{C}$ & 5.62 & $g h$ & 6.14 & $\mathrm{e}$ & 5.93 & efg & $5.49 \mathrm{~h}$ & 5.79 & & 76.42 & 77.67 & 82.70 & 83.30 & $80.02 \mathrm{~B}$ \\
\hline K 2 & $4.63 \mathrm{~cd}$ & $4.60 \mathrm{de}$ & $\begin{array}{r}4.37 \\
f-i\end{array}$ & $4.25 \mathrm{hij}$ & $4.46 \mathrm{~B}$ & 6.10 & ef & 6.24 & de & 6.11 & & $5.73 \mathrm{fgh}$ & 6.05 & & 75.48 & 76.50 & 81.50 & 81.82 & $78.83 \mathrm{C}$ \\
\hline K 3 & $\begin{array}{r}4.44 \\
\text { e-h }\end{array}$ & $4.79 \mathrm{bc}$ & $\begin{array}{r}4.46 \\
d-a\end{array}$ & $\mid \begin{array}{ll}4.1 & \mathrm{jk}\end{array}$ & $4.45 \mathrm{BC}$ & 6.25 & de & 6.95 & b & 6.53 & $\mathrm{~cd}$ & $5.42 \mathrm{hi}$ & 6.29 & B & 74.38 & 75.67 & 79.22 & 80.82 & $77.52 \mathrm{D}$ \\
\hline K 4 & $4.81 \mathrm{~b}$ & 5.03 & $4.62 \mathrm{cdt}$ & $4.40 \mathrm{fgh}$ & $\begin{array}{|ll|}4.72 & \mathrm{~A} \\
\end{array}$ & 6.56 & $\mathrm{~cd}$ & 7.52 & $a$ & 6.88 & $\mathrm{bc}$ & $5.99 \mathrm{efg}$ & 6.74 & A & 73.22 & 72.50 & 78.76 & 79.95 & $76.11 \mathrm{E}$ \\
\hline K 5 & $\begin{array}{c}4.34 \\
f-i\end{array}$ & $\begin{array}{c}4.30 \\
f-i\end{array}$ & $\begin{array}{r}4.28 \\
q-i\end{array}$ & $4.04 \mathrm{k}$ & $4.34 \mathrm{D}$ & 5.66 & $g h$ & 6.56 & $\mathrm{~cd}$ & 6.04 & ef & 5.11 & 5.84 & D & 78.56 & 78.67 & 83.78 & 83.88 & $81.22 \mathrm{~A}$ \\
\hline Mean & $4.54 \mathrm{~A}$ & $4.64 \mathrm{~A}$ & $4.41 \mathrm{~B}$ & $\begin{array}{|ll|}4.20 & \mathrm{C} \\
\end{array}$ & & 6.04 & C & \begin{tabular}{|l|}
6.68 \\
\end{tabular} & A & 6.30 & $B$ & $5.55 \mathrm{D}$ & & & 75.61 B & $76.20 \mathrm{~B}$ & $81.19 \mathrm{~A}$ & $81.96 \mathrm{~A}$ & \\
\hline
\end{tabular}


Gowda, A. M.

Table (9) : Effect of different organic manure sources and potassium addition on TSS, acidity and total sugars during 2005 and 2006 seasons

\begin{tabular}{|c|c|c|c|c|c|c|c|c|c|c|c|c|c|c|c|}
\hline \multirow{2}{*}{\begin{tabular}{|c|}
$\begin{array}{c}\text { Characteri } \\
\text { stics }\end{array}$ \\
Treat. \\
\end{tabular}} & \multicolumn{5}{|c|}{ TSS \% } & \multicolumn{5}{|c|}{ Acidity \% } & \multicolumn{5}{|c|}{ Total sugars \% } \\
\hline & $\begin{array}{l}\text { Cattle } \\
\text { nanure }\end{array}$ & \begin{tabular}{|c|}
$\begin{array}{c}\text { Sheep } \\
\text { manure }\end{array}$ \\
\end{tabular} & $\begin{array}{l}\text { Chicken } \\
\text { manure }\end{array}$ & Cc & Mean & \begin{tabular}{|c|} 
Cattle \\
manure
\end{tabular} & \begin{tabular}{|c|}
$\begin{array}{c}\text { Sheep } \\
\text { manure }\end{array}$ \\
\end{tabular} & $\begin{array}{l}\text { Chicken } \\
\text { manure }\end{array}$ & & Mean & $\begin{array}{ll}\text { e } \\
\text { re }\end{array}$ & \begin{tabular}{|c|} 
Sheep \\
manure
\end{tabular} & $\begin{array}{l}\text { Chicken } \\
\text { manure }\end{array}$ & Cont & Mean \\
\hline & \multicolumn{15}{|c|}{2005 season } \\
\hline K 1 & 4.87 & 5.40 & 14.80 & 14.53 & $\mid 14.90 \mathrm{D}$ & $0.386 \mathrm{~cd}$ & $0.321 \mathrm{ij}$ & $0.354 \mathrm{fg}$ & $0.417 \mathrm{~b}$ & 0.37 & 16.16 & 16.50 & 16.86 & 4.12 & $5.91 \mathrm{~B}$ \\
\hline K 2 & 15.33 & 15.47 & 15.00 & 15.20 & $15.25 \mathrm{C}$ & $|0.381 \mathrm{~cd}|$ & $0.311 \mathrm{jk}$ & $\begin{array}{c}0.337 \\
\text { ahi }\end{array}$ & $390 \mathrm{~cd}$ & $5 \mathrm{C}$ & 16.77 & 17.22 & 17.50 & 4.31 & \\
\hline K 3 & 16.20 & 16.53 & 15.67 & 15.27 & $15.92 \mathrm{~B}$ & de & $0.307 \mathrm{jk}$ & $0.332 \mathrm{hi}$ & $0.334 \mathrm{hi}$ & $0.336 \mathrm{D}$ & 16.66 & 16.68 & 16.11 & 14.50 & \\
\hline K 4 & 16.33 & 17.27 & 16.47 & 16.33 & $16.60 \mathrm{~A}$ & $\begin{array}{c}0.345 \\
f a h\end{array}$ & $0.295 \mathrm{k}$ & $\begin{array}{c}0.344 \\
\text { fah }\end{array}$ & $4 \mathrm{de}$ & $0.340 \mathrm{D}$ & 16.84 & 17.00 & 18.09 & 15.81 & $16.94 \mathrm{~A}$ \\
\hline K5 & 15.20 & 15.20 & 15.20 & 15.33 & $15.23 \mathrm{C}$ & $0.394 \mathrm{c}$ & $0.357 \mathrm{ef}$ & $0.383 \mathrm{~cd}$ & $0.455 \mathrm{a}$ & $0.397 \mathrm{~A}$ & 15.36 & 15.57 & 15.12 & 14.18 & 5.06 \\
\hline \multirow[t]{2}{*}{ Mean } & $\begin{array}{c}15.59 \\
B^{\star}\end{array}$ & $15.97 \mathrm{~A}$ & $15.43 \mathrm{~B}$ & $15.33 \mathrm{~B}$ & & $0.376 \mathrm{~B}$ & $0.318 \mathrm{D}$ & $0.350 \mathrm{C}$ & $0.394 \mathrm{~A}$ & & $16.36 \mathrm{~A}$ & $16.60 \mathrm{~A}$ & $16.74 \mathrm{~A}$ & $14.59 \mathrm{~B}$ & \\
\hline & \multicolumn{15}{|c|}{2006 season } \\
\hline K 1 & $\begin{array}{c}16.27 \\
\text { de }\end{array}$ & $16.13 \mathrm{de}$ & $\begin{array}{c}16.73 \\
\text { cde }\end{array}$ & $15.73 \mathrm{de}$ & $\begin{array}{c}16.22 \\
\text { CD }\end{array}$ & $0.339 \mathrm{f}$ & $0.340 \mathrm{f}$ & $0.432 \mathrm{~d}$ & $0.527 \mathrm{~b}$ & $0.410 \mathrm{~B}$ & 15.44 ef & $\begin{array}{l}16.15 \\
\text { cde }\end{array}$ & $\begin{array}{c}15.82 \\
\text { def }\end{array}$ & $14.53 \mathrm{gh}$ & 15.48 \\
\hline$n<$ & $\begin{array}{c}16.53 \\
\mathrm{de}\end{array}$ & $\begin{array}{c}17.33 \\
\text { bcd }\end{array}$ & $\begin{array}{c}17.20 \mathrm{~b}- \\
\mathrm{e}\end{array}$ & de & $\begin{array}{c}16.78 \\
B C\end{array}$ & $0.314 \mathrm{~g}$ & $0.313 \mathrm{~g}$ & $0.420 \mathrm{~d}$ & $0.493 \mathrm{c}$ & $0.385 \mathrm{C}$ & $16.38 \mathrm{~cd}$ & $17.89 \mathrm{~b}$ & $\begin{array}{c}15.73 \\
\text { def }\end{array}$ & $15.23 \mathrm{fg}$ & $16.31 \mathrm{~B}$ \\
\hline K 3 & $\begin{array}{c}17.07 \\
b-e\end{array}$ & $18.20 \mathrm{bc}$ & $\begin{array}{c}17.00 \mathrm{~b}- \\
\mathrm{e}\end{array}$ & e. & B & 0. & $\begin{array}{l}0.302 \\
\mathrm{gh}\end{array}$ & e & d & & i-f & $16.89 \mathrm{c}$ & $\begin{array}{c}15.91 \\
\text { def }\end{array}$ & & 16.14 B \\
\hline K 4 & $\begin{array}{c}20.00 \\
a \\
\end{array}$ & $20.33 \mathrm{a}$ & $18.40 \mathrm{~b}$ & $16.47 \mathrm{de}$ & $18.80 \mathrm{~A}$ & 0.250 & $0.286 \mathrm{~h}$ & $0.349 \mathrm{f}$ & $0.394 \mathrm{e}$ & $0.320 \mathrm{E}$ & $18.10 \mathrm{~b}$ & $18.87 \mathrm{a}$ & $\begin{array}{l}16.18 \\
\text { cde }\end{array}$ & & 17.25 \\
\hline 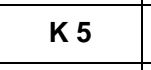 & $\begin{array}{c}15.93 \\
\text { de }\end{array}$ & $16.47 \mathrm{de}$ & $15.73 \mathrm{de}$ & $15.53 \mathrm{e}$ & $15.92 \mathrm{D}$ & $0.345 \mathrm{f}$ & $0.350 \mathrm{f}$ & $0.433 \mathrm{~d}$ & $0.578 \mathrm{a}$ & $0.426 \mathrm{~A}$ & $15.21 \mathrm{fg}$ & $\begin{array}{c}15.99 \\
\text { def }\end{array}$ & $\begin{array}{c}15.90 \\
\text { def }\end{array}$ & $14.32 \mathrm{~h}$ & $15.35 \mathrm{C}$ \\
\hline ean & A $^{17.16}$ & $7.69 \mathrm{~A}$ & $17.01 \mathrm{~A}$ & $15.96 \mathrm{~B}$ & & $0.303 \mathrm{D}$ & C & $2 \mathrm{~B}$ & $0.484 \mathrm{~A}$ & & $.24 \mathrm{~B}$ & 17.16 A & $15.91 \mathrm{~B}$ & $3 \mathrm{C}$ & \\
\hline
\end{tabular}

Means having * the same letters or ${ }^{* *}$ not having letters are not significantly differ at $5 \%$ level . 


\begin{tabular}{|c|c|c|c|c|c|c|c|c|c|c|c|c|c|c|c|}
\hline \multirow{2}{*}{\begin{tabular}{|c|}
$\begin{array}{c}\text { Characteri } \\
\text { stics }\end{array}$ \\
Treat.
\end{tabular}} & \multicolumn{5}{|c|}{ Nitrogen $\%$} & \multicolumn{5}{|c|}{ Phosphorus \% } & \multicolumn{5}{|c|}{ Potassium \% } \\
\hline & $\begin{array}{c}\text { Cattle } \\
\text { manure }\end{array}$ & \begin{tabular}{|c|} 
Sheep \\
manure
\end{tabular} & $\begin{array}{l}\text { Chicken } \\
\text { manure }\end{array}$ & Control & Mean & \begin{tabular}{|c|} 
Cattle \\
manure
\end{tabular} & $\begin{array}{l}\text { Sheep } \\
\text { manure }\end{array}$ & $\begin{array}{l}\text { Chicken } \\
\text { manure }\end{array}$ & Control & Mean & \begin{tabular}{|c|} 
Cattle \\
manure
\end{tabular} & \begin{tabular}{c|} 
Sheep \\
manure
\end{tabular} & $\begin{array}{l}\text { Chicken } \\
\text { manure }\end{array}$ & Control & Mean \\
\hline & \multicolumn{15}{|c|}{2005 season } \\
\hline K 1 & $1.90 \mathrm{fg}$ & $2.02 \mathrm{de}$ & $1.89 \mathrm{fg}$ & $1.83 \mathrm{gh}$ & $1.91 \mathrm{C}$ & $\begin{array}{c}0.26 \\
d-h\end{array}$ & $0.27 \mathrm{cde}$ & $\begin{array}{r}0.27 \\
d-g \\
\end{array}$ & $0.22 \mathrm{kl}$ & $0.26 \mathrm{~B}$ & $0.81 \mathrm{jk}$ & $0.90 \mathrm{ghi}$ & $1.09 \mathrm{~d}$ & $0.86 \mathrm{ij}$ & $0.91 \mathrm{C}$ \\
\hline K 2 & $1.70 \mathrm{ij}$ & $1.79 \mathrm{~g}-\mathrm{j}$ & j $1.72 \mathrm{hij}$ & $1.73 \mathrm{hij}$ & $1.74 \mathrm{E}$ & $\begin{array}{c}0.26 \\
\text { e-h }\end{array}$ & $0.29 a b c$ & $0.28 \mathrm{bcd}$ & $\begin{array}{r}0.23 \\
\mathrm{kl}\end{array}$ & $0.26 \mathrm{~B}$ & $0.85 \mathrm{ij}$ & 0.97 ef & $1.18 \mathrm{c}$ & $0.95 \mathrm{fg}$ & $0.99 \mathrm{~B}$ \\
\hline K 3 & $2.14 \mathrm{bc}$ & $2.37 \quad \mathrm{a}$ & $2.21 \quad b$ & $1.98 \mathrm{ef}$ & $2.18 \mathrm{~A}$ & $0.28 \mathrm{bcd}$ & $0.29 \mathrm{ab}$ & $0.30 \quad \mathrm{a}$ & $0.25 \mathrm{hij}$ & 0.28 A & 0.88 hi & $0.93 \mathrm{fgh}$ & $1.27 \mathrm{~b}$ & $0.92 \mathrm{fgh}$ & $1.00 \mathrm{~B}$ \\
\hline K 4 & $\begin{array}{l}2.04 \\
\text { cde }\end{array}$ & $2.17 \mathrm{~b}$ & $\begin{array}{l}2.13 \\
\mathrm{bcd}\end{array}$ & $1.86 \mathrm{fg}$ & $2.05 \mathrm{~B}$ & $0.25 \mathrm{fgh}$ & $\begin{array}{r}0.27 \\
d-g\end{array}$ & $\begin{array}{c}0.27 \\
c-f \\
\end{array}$ & $\begin{array}{r}0.26 \\
d-h \\
\end{array}$ & $0.26 \mathrm{~B}$ & $1.08 \mathrm{~d}$ & $1.25 \mathrm{~b}$ & $1.34 \quad \mathrm{a}$ & $1.01 \mathrm{e}$ & $1.17 \mathrm{~A}$ \\
\hline K5 & $1.86 \mathrm{~g}$ & $1.84 \mathrm{gh}$ & $1.81 \mathrm{ghi}$ & 1.68 & $1.80 \mathrm{D}$ & $0.23 \mathrm{ijk}$ & $\begin{array}{c}0.26 \\
\text { e-h }\end{array}$ & $0.25 \mathrm{ghi}$ & 0.21 & $0.24 \mathrm{C}$ & $0.78 \mathrm{k}$ & $0.86 \mathrm{ij}$ & 0.96 ef & 0.64 & $0.81 \mathrm{D}$ \\
\hline Mean & $1.93 \mathrm{~B}$ & $2.04 \mathrm{~A}$ & $1.95 \mathrm{~B}$ & $\begin{array}{ll}1.82 & C \\
\end{array}$ & & $0.26 \mathrm{~B}$ & $0.28 \mathrm{~A}$ & $0.27 A$ & $0.24 \mathrm{C}$ & & \begin{tabular}{ll|}
0.88 & $C$
\end{tabular} & $\begin{array}{|ll|}0.98 & \text { B } \\
\end{array}$ & \begin{tabular}{|ll}
1.17 & $A$
\end{tabular} \mid & $0.88 \mathrm{C}$ & \\
\hline K1 & \multicolumn{15}{|c|}{2006 season } \\
\hline n & $1.96 \mathrm{~h}$ & 2.09 ef & $1.93 \mathrm{hi}$ & $1.66 \mathrm{k}$ & $1.91 \quad \mathrm{D}$ & 0.22 & 0.23 & 0.25 & 0.19 & $0.22 \mathrm{D}$ & 0.85 hi & 0.94 efg & $1.00 \mathrm{de}$ & 0.74 & $0.88 \mathrm{D}$ \\
\hline
\end{tabular}

Table (10): Effect of different organic manure sources and potassium addition on leaf nitrogen, phosphorus and potassium percentages during 2005 and 2006 seasons. 


\section{Gowda, A. M.}

\begin{tabular}{|c|c|c|c|c|c|c|c|c|c|c|c|c|c|c|c|c|c|}
\hline K2 & $.00 \mathrm{~g}$ & \begin{tabular}{l|l}
$\mathrm{gh}$ & 2.00
\end{tabular} & $\operatorname{gh} \mid 2.06$ & \begin{tabular}{l|l}
$\mathrm{fg}$ & 1.81
\end{tabular} & & 1.97 & & 0.24 & 0.25 & 25 & 0.20 & 0.24 & .95 efg & .15 & \begin{tabular}{l|l}
$\mathbf{C}$ & 1.16
\end{tabular} & fgh & $1.04 \mathrm{C}$ \\
\hline K 3 & $2.26 \mathrm{~b}$ & $\begin{array}{ll}\text { bc } & 2.45 \\
\end{array}$ & $\begin{array}{ll}\text { a } 2.15 \\
\end{array}$ & $\begin{array}{lll}\text { de } & 1.88 \\
\end{array}$ & & 2.18 & A & 0.25 & 0.27 & 0.26 & 0.20 & $0.25 \mathrm{~B}$ & B & 1.25 & $\begin{array}{ll}\text { b } 1.30 \\
\end{array}$ & hi & $\begin{array}{l}\mathrm{i} \\
\end{array}$ \\
\hline K 4 & $2.21 \mathrm{C}$ & \begin{tabular}{l|l}
$\mathrm{cd}$ & 2.31 \\
\end{tabular} & $\begin{array}{ll}b 2.10 \\
\end{array}$ & \begin{tabular}{l|l} 
ef & 1.85 \\
\end{tabular} & & 2.12 & B & & & & & 0.27 A & \begin{tabular}{l|l} 
A & 1.29 \\
\end{tabular} & 1.31 & & $8 \mathrm{def}$ & f 1.26 \\
\hline K5 & \begin{tabular}{|l|}
1.86 \\
\end{tabular} & 1.86 & \begin{tabular}{l|l}
$j$ & 1.86 \\
\end{tabular} & $\begin{array}{ll}\text { ij } & 1.60\end{array}$ & $\mathrm{k}$ & 1.80 & $E$ & 0.20 & 0.20 & 0.23 & 0.15 & $0.20 \mathrm{E}$ & \begin{tabular}{|l|l|}
$\mathbf{E}$ & 0.77 \\
\end{tabular} & & 5 efg & & $0.81 \mathrm{E}$ \\
\hline Mean & 2.06 & \begin{tabular}{l|l} 
B & 2.14 \\
\end{tabular} & \begin{tabular}{|l|l|} 
A & 2.02 \\
\end{tabular} & \begin{tabular}{l|l}
$C$ & 1.78
\end{tabular} & & & & \begin{tabular}{|l|}
0.24 \\
\end{tabular} & & .26 & $0.20 \mathrm{C}$ & & 0.98 & & 5 & 5 & \\
\hline
\end{tabular}


Means having the same letters or not having letters are not significantly differ at $5 \%$ level. Means having the same letters or not having letters are not significantly differ at $5 \%$ level.

Means having the same letters or not having letters are not significantly differ at $5 \%$ level.

Means having the same letters or not having letters are not significantly differ at $5 \%$ level.

Means having the same letters or not having letters are not significantly differ at $5 \%$ level.

Means having the same letters or not having letters are not significantly differ at $5 \%$ level.

Means having the same letters or not having letters are not significantly differ at $5 \%$ level.

Means having the same letters or not having letters are not significantly differ at $5 \%$ level. 


\section{Gowda, A. M.}

Means having the same letters or not having letters are not significantly differ at $5 \%$ level. 